Elsevier required licence: (C) $<2018>$. This manuscript version is made available under the CC-BY-NC-ND 4.0 license http://creativecommons.org/licenses/bync-nd/4.0/ 


\title{
Partial nitrification granular sludge reactor as a pretreatment for anaerobic ammonium oxidation (Anammox): achievement, performance and microbial community
}

\author{
Dong Wei ${ }^{\text {a }}$, Huu Hao $\mathrm{Ngo}^{\mathrm{b}}$, Wenshan Guo ${ }^{\mathrm{b}}$, Weiying $\mathrm{Xu}{ }^{\mathrm{a}}$, Bin $\mathrm{Du}^{\mathrm{a}}{ }^{*}$, Qin Wei ${ }^{\mathrm{c}}$ \\ ${ }^{a}$ School of Resources and Environment, University of Jinan, Jinan 250022, PR China \\ ${ }^{b}$ School of Civil and Environmental Engineering, University of Technology Sydney, Broadway, NSW \\ 2007, Australia \\ ${ }^{c}$ Key Laboratory of Chemical Sensing \& Analysis in Universities of Shandong, School of Chemistry \\ and Chemical Engineering, University of Jinan, Jinan 250022, PR China
}

\begin{abstract}
Partial nitrification granular sludge was successfully cultivated in a sequencing batch reactor as a pretreatment for anaerobic ammonium oxidation (Anammox) through shortening settling time. After 250-days operation, the effluent $\mathrm{NH}_{4}{ }^{+}-\mathrm{N}$ and $\mathrm{NO}_{2}{ }^{-}-\mathrm{N}$ concentrations were average at 277.5 and $280.5 \mathrm{mg} / \mathrm{L}$ with nitrite accumulation rate of $87.8 \%$, making it as an ideal influent for Anammox. Simultaneous free ammonia (FA) and free nitrous acid (FNA) played major inhibitory roles on the activity of nitrite oxidizing bacteria (NOB). The MLSS and $\mathrm{SVI}_{30}$ of partial nitrification reactor were $14.6 \mathrm{~g} / \mathrm{L}$ and $25.0 \mathrm{~mL} / \mathrm{g}$, respectively. Polysaccharide (PS) and protein (PN) amounts in extracellular polymeric substances (EPS) from granular sludge were about 1.3 and 2.8 times higher than from seed sludge. High-throughput pyrosequencing results indicated that Nitrosomonas affiliated to the ammonia oxidizing bacteria (AOB) was

\footnotetext{
* Corresponding author. Tel: +86 5318276 7370; fax: +86 53182767370.

E-mail address: dubin61@gmail.com (B. Du)
} 
the predominant group with a proportion of $24.1 \%$ in the partial nitrification system.

Keywords: Partial nitrification; Granular sludge; Extracellular polymeric substances; Free ammonia (FA); Microbial community.

\section{Introduction}

Biological nitrogen removal from municipal and industrial wastewaters is commonly accomplished in two separate steps via aerobic nitrification and anoxic denitrification (Lackner et al., 2014). As a novel autotrophic nitrogen removal approach, anaerobic ammonium oxidation (Anammox) has been developed as an efficient, cost-effective and environmental-friendly alternative to conventional nitrogen removal process (Okabe et al., 2011). In this biological process, nitrite and ammonium ions are converted directly into diatomic nitrogen and water in the absence of oxygen and organic carbon, causing the advantages of a higher nitrogen removal rate (NRR), lower operational costs, and smaller space requirements, especially when treating ammonium-rich wastewater (Ma et al., 2016). Till now, full-scale Anammox has been successfully applied for the treatment of various nitrogen-rich wastewaters, such as reject water, sludge-digestion liquid and landfill leachate pharmaceutical wastewater etc (Joss et al., 2009).

For successful application of Anammox process, partial nitrification around 50\% of ammonium to nitrite is an essential pretreatment since Anammox process depends on the availability of both ammonia nitrogen and nitrite in the influent. The key operational strategy to achieve partial nitrification process is the enrichment of 
ammonia oxidizing bacteria (AOB) and limitation-inhibition-washout of nitrite oxidizing bacteria (NOB). Till now, many influencing factors have been successfully applied to achieve and maintain the accumulation of nitrite in partial nitrification system, such as low dissolved oxygen (DO), high temperature, high free ammonia (FA), high free nitrous acid (FNA), and suitable sludge retention time (SRT) etc (Blackburne et al., 2008; Guo et al., 2010; Pollice et al., 2002). Among all above methods, low DO supply has been wildly reported as an effective strategy that leads to NOB repression in a variety of reactor configurations, since the oxygen affinity constants of $\mathrm{AOB}$ and $\mathrm{NOB}$ are reported at 0.3 and $1.1 \mathrm{mg} / \mathrm{L}$, respectively. However, controlling DO at low level may be responsible for the occurrence of filamentous organism overgrowth, bringing about poor sludge settling property and substandard effluent in the reactor (Bao et al., 2009). Additionally, sustained low DO-supply also reduces the nitrification rate and therefore extends hydraulic retention time (HRT) of flocculent-sludge based system. Moreover, nitrifying bacteria are difficult to be maintained in conventional activated sludge owing to their lower growth rates and the ability for DO competition to heterotrophic bacteria (Wan et al., 2013). Thereby, it is desirable to explore a feasible of high-performance partial nitrification system to overcome the above disadvantages.

Aerobic granular sludge, as a novel biotechnology, has been successfully developed and applied for various municipal and industrial nitrogen-rich wastewaters treatment (Rathnayake et al., 2013; Vázquez-Padín et al., 2010; Liang et al., 2015). Because of the unique granule attributes, aerobic granular sludge has a denser and stronger microbial aggregate structure, a higher biomass concentration, and more 
excellent settleability than conventional activated sludge (Adav et al., 2008).

Moreover, use of a sequencing batch granular sludge system negates the need for a secondary clarifier, further saving space and conserving energy. Additionally, it has great ability to withstand shock loadings for treating high-strength wastewater because of its unique granular structure (Liu et al., 2009). Therefore, it is of great interesting to achieve partial nitrification via granular sludge-based system for ideal influent for Anammox. As an operating parameter for aerobic granulation, it is demonstrated that sufficient oxygen supply in the reactor may cause enough shear force that would increase the cell surface hydrophobicity and break down overgrown filaments for the formation of granular sludge (Gao et al., 2011). Thereby, this cultivation strategy is difficult to selective wash-out of NOB to establish an enriched nitrification culture because NOB could be accumulated easily under higher DO control that lead to a high nitrate concentration and deteriorate nitrogen removal performance (Miao et al., 2017). However, since most of industrial wastewaters containing high strength ammonia nitrogen concentration $(>500 \mathrm{mg} / \mathrm{L})$, it is possible that the influent FA is selected as key strategy to achieve nitrite accumulation due to its different inhibition values on $\mathrm{AOB}$ and NOB even at higher DO-supply (Wei et al., 2014). Additionally, FNA produced from nitrite accumulation could significantly inhibit the NOB activity even at very low levels. Moreover, NOB are more sensitive to the two kinds of inhibitors (FA and FNA) than those of AOB. Hence, it is possible that the high influent ammonia concentration coupled with appropriate aeration lead to the washout of NOB for the formation of partial nitrification granular sludge.

Accordingly, the objective of present study was to evaluate the feasibility of cultivating partial nitrification granular sludge as a pretreatment for Anammox. 
Shortening settling time and stepwise of influent ammonia increase were applied for the purpose of AOB enriched granulation. The physicochemical characteristics and microbial community of partial nitrification granular sludge were also comprehensively investigated. The obtained result would be potentially significant for developing partial nitrification system in the form of granular sludge.

\section{Materials and methods}

\subsection{Reactor set-up and operational mode}

Experiment was performed in a cylindrical laboratory-scale SBR with a working volume of $6.28 \mathrm{~L}$ ( $10 \mathrm{~cm}$ in internal diameter and $80 \mathrm{~cm}$ in height, respectively). The reactor was continuously operated for more than 250 days. Influent wastewater was prepared in a storage tank $(60 \mathrm{~L})$ and introduced to the bottom of the reactor by using a water pump, and the effluent was drawn at middle height of the reactor with volumetric exchange ratio of $50 \%$. As a result, the daily feeding volume of wastewater into the SBR was about 12.6 L. The DO concentration was controlled relatively high (in the range of $2-4 \mathrm{mg} / \mathrm{L}$ ) during aeration process to provide enough hydrodynamic shear force for sludge granulation. The reactor was maintained at room temperature $\left(25-28^{\circ} \mathrm{C}\right)$ throughout the study. A time controller was installed to achieve the reactor automatic operation.

The SBR was successively operated in anoxic/aerobic mode with $6 \mathrm{~h}$ one cycle, consisted of $5 \mathrm{~min}$ for influent filling, 25 min anoxic process and $300 \mathrm{~min}$ for aeration process. A settling time of $20 \mathrm{~min}$ in the start-up stage was applied to retain most of sludge and gradually reduced to $2 \mathrm{~min}$ (phase I, days 1-85) to washout of free-living 
and floc-forming microorganisms. After the successful formation of partial nitrification granular sludge (phases II and III, days 86-250), the settling time of 2 min was remained to the end of study. The rest of time was used for effluent removal and idle. SRT could not be controlled precisely because of the washout of poorly settled sludge by shortening settling time.

\subsection{Nitrogen-rich wastewater and seed sludge}

Since many real ammonium-rich wastewaters accompanied by a relatively high organic content, therefore organic matter was added in the influent for partial nitrification system. The compositions of synthetic wastewater were as follows: Chemical oxygen demand (COD, as $\left.\mathrm{CH}_{3} \mathrm{COONa}\right) 600 \mathrm{mg} / \mathrm{L} ; \mathrm{K}_{2} \mathrm{HPO}_{4}, 112 \mathrm{mg} / \mathrm{L}$; $\mathrm{CaCl}_{2}, 40 \mathrm{mg} / \mathrm{L} ; \mathrm{MgSO}_{4} \cdot 2 \mathrm{H}_{2} \mathrm{O}, 20 \mathrm{mg} / \mathrm{L} ; \mathrm{FeSO}_{4} \cdot 2 \mathrm{H}_{2} \mathrm{O}, 20 \mathrm{mg} / \mathrm{L}$ and microelement solution $1.0 \mathrm{ml} / \mathrm{L}$. To select for a partial nitrification culture, the influent ammonia concentration increased from 700 to $800 \mathrm{mg} / \mathrm{L}$. The influent $\mathrm{pH}$ values were adjusted to 7.5 to 8.5 by adding $\mathrm{NaHCO}_{3}$. It could be noticed that $\mathrm{NH}_{4}{ }^{+}-\mathrm{N}$ was the dominate pollutant and $\mathrm{COD} / \mathrm{N}$ ratio averaged as low as $0.70-0.85$.

The seed sludge inoculated into SBR was collected from an aeration unit of a WWTP treating the effluent of an internal circulation (IC) reactor $\left(2500 \mathrm{~m}^{3} /\right.$ day). The influent COD and $\mathrm{NH}_{4}{ }^{+}-\mathrm{N}$ concentrations of aeration unit were about 1000 and 250 $\mathrm{mg} / \mathrm{L}$, respectively. The seed sludge has been also applied for cultivation of aerobic granular sludge in a pilot-scale SBR (Wei et al., 2012). Nitrite accumulation was observed in the start of reactor with the influent $\mathrm{COD} / \mathrm{N}$ ratios of 3.32-6.37. Due to 
the selection of high temperature $\left(30^{\circ} \mathrm{C}\right)$ and high FA concentration $(1.09-2.03 \mathrm{mg} / \mathrm{L})$ of IC effluent, the activity of AOB in aeration unit was much higher than that of NOB, as evidenced by the high nitrite accumulation in the pilot-scale SBR even at high DO concentration (Wei et al., 2012). The initial mixed liquor suspended solids (MLSS) concentration and sludge volume index (SVI) of the seed sludge in the laboratory-reactor were about $4.0 \mathrm{~g} / \mathrm{L}$ and $64.5 \mathrm{~mL} / \mathrm{g}$, respectively.

\subsection{Extracellular polymeric substances extraction and analysis}

Extracellular polymeric substances (EPS) from seed sludge and granular sludge were extracted by using a heating method and detailed procedure could be found in the previous literature (Li and Yang, 2007). Polysaccharide (PS) content was measured by means of phenol-sulphuric acid method by using glucose as the standard, while the protein $(\mathrm{PN})$ content was measured by means of modified Lowry method by using bovine serum albumin (BSA) as the standard. EEM spectra of extracted EPS were recorded by luminescence spectrometry (LS-55, Perkin-Elmer Co., USA). EEM of excitation spectra were subsequently scanned from 200 to 400 with $10 \mathrm{~nm}$ increment by varying the excitation wavelength from 280 to $550 \mathrm{~nm}$.

\subsection{Analytical methods}

$\mathrm{NH}_{4}{ }^{+}-\mathrm{N}, \mathrm{NO}_{2}{ }^{-}-\mathrm{N}, \mathrm{NO}_{3}{ }^{-}-\mathrm{N}, \mathrm{COD}, \mathrm{MLSS}, \mathrm{MLVSS}, \mathrm{SVI}_{30}$ and $\mathrm{SVI}_{5}$ were tested by using their standard methods (APHA, 2005). Size distribution analysis of seed activated sludge was obtained by a laser scattering particle size distribution analyzer (LS13320, Beckman Coulter, Inc., USA), whereas formed granular was determined 
with a standard sample sieve $(0.5$ to $4 \mathrm{~mm})$. The microstructure and morphology of sludge were analyzed by using an optical microscope (IX51, Olympus Co., Ltd., Japan). DNA was extracted by using a MOBIO PowerSand ${ }^{\mathrm{TM}}$ DNA kit (MOBIO, Carlsbad, CA) according to the manufacturer's instructions. High-throughput pyrosequencing analysis was performed in the Chinese National Human Genome Sequencing Center (Shanghai).

Since the COD measurement was based on oxidation by potassium dichromate, it was influenced by nitrite (oxidized into nitrate). Thus COD value was corrected in order to estimate the oxygen demand only due to the organic substances.

$$
\mathrm{COD}=\mathrm{COD}_{\text {total }}-\mathrm{COD}_{\text {nitrite }}=\mathrm{COD}_{\text {total }}-0.5\left(\mathrm{NO}_{2}^{-}-\mathrm{N}\right) \mathrm{M}_{\mathrm{O}_{2}} / \mathrm{M}_{\mathrm{N}}
$$

Nitrite accumulation ratio (NAR) of the reactor was calculated according to the following equation (Eq. (2)):

$$
\mathrm{NAR}(\%)=\frac{\mathrm{NO}_{2}^{-}-\mathrm{N}}{\mathrm{NO}_{2}^{-}-\mathrm{N}+\mathrm{NO}_{3}^{-}-\mathrm{N}} \times 100 \%
$$

FA and FNA concentrations were estimated by the following expressions (Eqs. (3)

- (6)) proposed by Anthonisen et al. (1976):

$$
\begin{aligned}
& \text { FA as } \mathrm{NH}_{3}(\mathrm{mg} / \mathrm{L})=\frac{17}{14} \times \frac{\text { total ammonia as } \mathrm{N}(\mathrm{mg} / \mathrm{L}) \times 10^{\mathrm{pH}}}{K_{b} / K_{w}+10^{\mathrm{pH}}} \\
& \text { FN A as } \mathrm{HNO}_{2}(\mathrm{mg} / \mathrm{L})=\frac{46}{14} \times \frac{\mathrm{NO}_{2}^{-}-\mathrm{N}(\mathrm{mg} / \mathrm{L})}{K_{a} \times 10^{\mathrm{pH}}} \\
& \frac{K_{b}}{K_{w}}=\mathrm{e}^{6334 /(273+\mathrm{T})} \\
& K_{a}=\mathrm{e}^{-2300 /(273+\mathrm{T})}
\end{aligned}
$$

Where $K_{b}$ is the ionization constant of the ammonia equilibrium, $K_{w}$ is the 
ionization constant of water and $K_{a}$ is the ionization constant of the nitrous acid equilibrium.

\section{Results and discussion}

\subsection{Achievement and maintenance of partial nitrification granular reactor}

Fig. 1 shows the evolution of nitrogen compounds in the influent and effluent during the achievement and maintenance of partial nitrification granular sludge reactor. According to the influent $\mathrm{NH}_{4}{ }^{+}-\mathrm{N}$ concentration in the SBR, this study could be divided into three stages: phase I (days 1-85, $700 \mathrm{mg} / \mathrm{L}$ ), phase II (days 86-185, $750 \mathrm{mg} / \mathrm{L}$ ), phase III (days 186-250, $800 \mathrm{mg} / \mathrm{L}$ ). In the initial phase I (days 1 to 30 ), the effluent $\mathrm{NH}_{4}{ }^{+}-\mathrm{N}$ and $\mathrm{NO}_{2}{ }^{-}-\mathrm{N}$ concentrations were 134.7 and $318.6 \mathrm{mg} / \mathrm{L}$ at day 1 , whereas those values changed to 151.2 and $239.2 \mathrm{mg} / \mathrm{L}$ at day 30 , respectively. In contrast, the effluent $\mathrm{NO}_{3}-\mathrm{N}$ concentrations generally decreased from 59.1 to 42.1 $\mathrm{mg} / \mathrm{L}$, suggesting that the activity of NOB was generally inhibited in the system. After keeping on 70 days of operation, the effluent of $\mathrm{NH}_{4}{ }^{+}-\mathrm{N}$ and $\mathrm{NO}_{2}^{-}-\mathrm{N}$ concentrations were changed to 240.1 and $211.7 \mathrm{mg} / \mathrm{L}$ due to the reduced aeration rate of system for the ratio of $\mathrm{NH}_{4}{ }^{+}-\mathrm{N} / \mathrm{NO}_{2}{ }^{-}-\mathrm{N}$ as $1: 1.3$.

It is well accepted that FA is a competitive inhibitor of nitrite oxidoreductase activity, whose inhibition values for $\mathrm{AOB}$ and NOB were in the ranges of 10-150 and 0.1-1.0 mg/L, respectively (Anthonisen et al., 1976). In the present study, the inhibition of NOB activity was mainly controlled by stepwise increase $\mathrm{NH}_{4}{ }^{+}-\mathrm{N}$ concentration for providing enough FA value in the start-up period of system. 
According to the typical cycle in the phase I (day 57), $\mathrm{NH}_{4}{ }^{+}-\mathrm{N}$ concentration decreased continuously from 445.2 to $179.7 \mathrm{mg} / \mathrm{L}$ as aeration proceeded, whereas $\mathrm{NO}_{2}-\mathrm{N}$ concentration increased from 101.1 to $272.0 \mathrm{mg} / \mathrm{L}$ in the effluent.

Correspondingly, FA concentration was high of $38.0 \mathrm{mg} / \mathrm{L}$ in the influent $(\mathrm{pH}$ at 7.8 ) and increased to $97.1 \mathrm{mg} / \mathrm{L}$ after anoxic process ( $\mathrm{pH}$ at 8.5), which was much higher than the inhibition value of NOB $(1.0 \mathrm{mg} / \mathrm{L})$. Therefore, the FA in the influent played a certain role on inhibition activity of NOB to achieve nitrite aceumulation. However, a decreased $\mathrm{pH}$ throughout nitrification process (from 8.5 to 6.5) by AOB could help NOB survive by decreasing the FA concentration at $4.5 \mathrm{~h}$ (Park et al., 2015). At the same time, it was noteworthy that the FNA concentration increased from 0.304 to $0.623 \mathrm{mg} / \mathrm{L}$ in the effluent by the nitrite accumulation and $\mathrm{pH}$ decrease. It is estimated that the FNA concentration could affect NOB activity at approximately $0.011 \mathrm{mg} / \mathrm{L}$, and completely inhibition at $0.023 \mathrm{mg} / \mathrm{L}$ (Vadivelu et al., 2006). Thereby, it is possible that the FNA sustained the inhibitory effect of NOB from $4.5 \mathrm{~h}$ till the end of cycle. It was also proved that $\mathrm{NO}_{3}{ }^{-}-\mathrm{N}$ concentration only increased from 48.6 to $49.2 \mathrm{mg} / \mathrm{L}$ even at increased DO concentrations (2.1 and $3.2 \mathrm{mg} / \mathrm{L}$ at 4.5 and $5.5 \mathrm{~h}$, respectively). Therefore, nitrite accumulation in present partial nitrification system was mainly caused by simultaneous FA and FNA inhibition effects.

The FA and/or FNA as one of the critical parameters for NOB activity inhibition have been widely applied for treating various wastewaters. Li et al. (2018) achieved partial nitrification by controlling the influent FA high of $70 \mathrm{mg} / \mathrm{L}$ under high $\mathrm{pH}$ value $(>8.0)$ and influent $\mathrm{NH}_{4}{ }^{+}-\mathrm{N}(200 \mathrm{mg} / \mathrm{L})$ in the influent wastewater. Zhang et al. 
(2010) also achieved stable and high-rate nitrogen removal from reject water by partial nitrification and subsequent Anammox, indicating that the values of FA and FNA within a favorable range were essential for the successful operation of partial nitrification reactor.

In phase II, the influent $\mathrm{NH}_{4}{ }^{+}-\mathrm{N}$ concentration increased from 700 to $750 \mathrm{mg} / \mathrm{L}$ in order to further enrichment of AOB. Data implied that $\mathrm{NH}_{4}{ }^{+}-\mathrm{N}$ was partially oxidized to $\mathrm{NO}_{2}{ }^{-}-\mathrm{N}$ with low produced $\mathrm{NO}_{3}{ }^{-}-\mathrm{N}$ concentration. Between days 86 and 185, the average effluent $\mathrm{NH}_{4}{ }^{+}-\mathrm{N}$ and $\mathrm{NO}_{2}{ }^{-}-\mathrm{N}$ concentrations were 234.5 and 266.7 $\mathrm{mg} / \mathrm{L}$, whereas the effluent $\mathrm{NO}_{3}{ }^{-}-\mathrm{N}$ concentration were average at $42.1 \mathrm{mg} / \mathrm{L}(n=29)$, making it as an ideal pretreatment system for Anammox. After the influent $\mathrm{NH}_{4}{ }^{+}-\mathrm{N}$ concentration increased to $800 \mathrm{mg} / \mathrm{L}$ (phase III), the effluent $\mathrm{NH}_{4}{ }^{+}-\mathrm{N}$ and $\mathrm{NO}_{2}{ }^{-}-\mathrm{N}$ concentrations both increased to 277.5 and $280.5 \mathrm{mg} / \mathrm{L}$, and the effluent $\mathrm{NO}_{3}{ }^{-}-\mathrm{N}$ concentration was average at $40.1 \mathrm{mg} / \mathrm{L}(n=10)$. Throughout the whole experiment, the result showed that the effluent NAR improved from $85.7 \%$ to $87.8 \%$ after long-term operation, suggesting that it was a reliable strategy to apply FA and FNA inhibition effects on nitrite accumulation. Additionally, it was found that the effluent COD concentration and removal efficiency of reactor was $50.8 \mathrm{mg} / \mathrm{L}$ and $91.5 \%$ at the end of study, respectively. Although COD was not fully degraded in the partial nitrification reactor, the residual COD concentration was low, and could not inhibit subsequent anaerobic ammonia oxidation bacteria (AAOB) effectively.

\subsection{Settling property and appearance structure of seed and granular sludges}

A settling time was gradually reduced to wash out of poor sludge for improving 
the sludge settleability in the start-up granulation process. At the beginning, the initial MLSS and MLVSS of SBR were average at 4.03 and $2.63 \mathrm{~g} / \mathrm{L}$, while the corresponding $\mathrm{SVI}_{5}$ and $\mathrm{SVI}_{30}$ were 87.3 and $64.5 \mathrm{~mL} / \mathrm{g}$, respectively (Fig. 2A). After three months of operation, MLSS and MLVSS obviously increased to 9.07 and 6.53 $\mathrm{g} / \mathrm{L}$, implying that decreasing the settle time effectively improved sludge settling performance of the partial nitrification system. Meanwhile, a significantly decreased $\mathrm{SVI}_{5} / \mathrm{SVI}_{30}$ ratio close to 1 was observed, suggesting the dominant presence of granules in the whole sludge. The enriched nitrifying population over heterotrophic population was mainly responsible for the lowered growth rate of partial nitrification granules at low $\mathrm{COD} / \mathrm{N}$ ratio of influent wastewater. However, the stability of partial nitrification granules could be improved by selecting slow-growing nitrifying bacteria (Liu et al., 2004). After 250-day of operation, MLSS and MLVSS of the granular sludge reactor were improved to 14.6 and $10.9 \mathrm{~g} / \mathrm{L}$, while both $\mathrm{SVI}_{30}$ and $\mathrm{SVI}_{5}$ values were both approximate at $25.0 \mathrm{~mL} / \mathrm{g}$, respectively. Due to the low SVI value, the separation of granular sludge from the liquid was quickly due to the good settleability.

Fig. 2B shows the size distributions of seed sludge and granular sludge in the partial nitrification reactor. It was found that the average diameter of seed sludge mostly ranged from 0.2 to $0.35 \mathrm{~mm}$. After 240 days operation, only a small fraction of diameter $(<0.5 \mathrm{~mm})$ accounting for less than $0.17 \%$ was found in the matured granules. Biomass with a diameter larger than $0.212 \mathrm{~mm}$ was considered as granular sludge, therefore the MLSS concentration in the SBR consisted of approximate 98\% granular sludge (Ni et al., 2009). The diameter between 3 and $4 \mathrm{~mm}$ were highly 
enriched and accounted for $38.4 \%$ of the total partial nitrification granular sludge. The size range of granular sludge in present study was much higher than that cultivated by domestic wastewater (Ni et al., 2009), soybean-processing wastewater ( $\mathrm{Su}$ and $\mathrm{Yu}$, 2005), and internal circulation (IC) anaerobic reactor effluent (Wei et al., 2012).

Additionally, microscopic examination showed that the appearance structure of granular sludge was completely different from the floc-like sludge. The seed activated sludge had a typical fluffy, irregular, loose morphology with brown color whereas the mature granular sludge had a much more regular, denser and clearer round-shaped structure, leading to a stable operation of the system towards the end of experiment. Weber et al. (2007) have reported that the mature aerobic granules consisted of bacteria, EPS, protozoa and, in some cases, fungi, and eukaryotic organisms play a crucial role in the formation of granules. In our previous study, lots of protozoa (e.g., Epistylis sp.) growing in a tree-like colony could be found at the surface of aerobic granular sludge (Wei et al., 2012).

\subsection{Variation of extracellular polymeric substances compositions}

As a complex high-molecular-weight mixture of polymers, EPS are mainly

composed by PS, PN, humic acids, nucleic acids and lipids etc (Sheng et al., 2010).

As shown in Fig. 3, EPS production was substantially enhanced under the stressful culture condition, and PN was the predominant component of EPS in the whole bio-granulation process. PN was the largest EPS fraction possibly due to the exoenzymes entrapped in EPS matrix (Wang et al., 2017). In contrast, PS was the predominant composition in pure microbial cultures or biofilms (D'Abzac et al., 
2010). It was found that the amounts of PN and PS were average at 28.8 and 3.53 $\mathrm{mg} / \mathrm{g}$ VSS in the seed sludge, respectively. At day 70, the metabolic pathway of sludge began to be regulated under the condition of high shear force, and those amounts significantly increased to 33.2 and $7.51 \mathrm{mg} / \mathrm{g}$ VSS corresponding to the formation of initial granules (at day 70), as similarly reported by Luo et al. (2014). Generally, EPS secreted by microorganisms are regarded to be helpful to initiate the aerobic granulation process, which is generally related to hydrophobicity, cell surface charge and bridging functions (Adav et al., 2008). After the partial nitrification granular sludge matured, those amounts significantly increased to 38.6 and $9.91 \mathrm{mg} / \mathrm{g}$ VSS at day 163, which were about 1.3 and 2.8 times higher than in the seed flocculent sludge. In particular, the amount of PN was about 3.9 times higher than that of PS in partial nitrification granular sludge (day 163), and the PN-rich EPS was considered to be beneficial to improve the structural stability of the granules (Iaconi et al., 2006). There is strong evidence that the composition as well as the content of EPS in biogranules affects long-term stability of granules (Liu et al., 2004). Laspidou and Rittmann (2002) proved that protein had a high content of negatively charged amino acids, which was more involved than sugars in electrostatic bonds with multivalent cations in stabilizing aggregate structure. At day 245, the total EPS from partial nitrification granular sludge $(49.7 \mathrm{mg} / \mathrm{g}$ VSS) was only $2.5 \%$ higher than EPS at day 163 (48.5 mg/g VSS), and the PN/PS ratio was consistent at 3.8. It has been reported that wastewater containing low carbon to nitrogen ratio tended to produce EPS with a high PN/PS ratio (Liu and Fang, 2003). In the present study, the EPS production and 
composition were comprehensively influenced by the changed environmental conditions, such as relatively high shear force, short settling time and periodical feast-famine period, and those factors significantly stimulated bacteria to produce more EPS for the formation and stability of biogranules.

\subsection{Fluorescent spectra observation of extracellular polymeric substances}

Fig. 4 shows the changes in 3D-EEM spectra of EPS samples from the partial nitrification sludge granulation process. Table 1 summarizes the detailed fluorescence spectral parameters of EPS samples, including fluorescence location as well as fluorescence intensity. It could be found from Fig. $4 \mathrm{~A}$ that two main fluorescence peaks (Peak A and Peak B) were indentified at excitation/emission (Ex/Em) wavelength of $290 / 361.5$ and $350 / 440 \mathrm{~nm}$ in the seed sludge, suggesting the presence of tryptophan PN-like substances and humic-like substances, respectively (Sheng and Yu, 2006). Compared to the EPS from aerobic granular sludge reported by Zhu et al. (2012), aromatic PN-like substances (Ex/Em of 220/358.5) was not identified in the partial nitrification granulation process. The reason may be attributed to the different system operating conditions (e.g. substrate, DO, HRT) as well as a shift in microbial community. In the initial granulation process (day 70), the intensity of Peak B generally increased from 591.2 to 726.5 a.u., implying the enrichment of humic-like substances in the granulation structure. Afterwards, Peak C was identified at Ex/Em of 320/402 nm (day 163), corresponding to the appearance of marine humic-like substances in the partial nitrification granular sludge (Chen et al., 2003). The intensity of Peak C was continually enhanced from 629.4 to 672.5 a.u. (day 245) during the 
long-term operation of granular reactor. Generally, Peak C was often detected in surface waters, particularly in lakes and oceans (Shammi et al., 2017). Tryptophan PN-like substances (Peak A) in EPS from seed sludge and granular sludge always expressed high intensity. Additionally, an obvious blue-shift in terms of emission wavelength was observed in Peak A, implying the changed chemical composition of PN substances during the achievement of granulation process. Extracellular PN is related to their hydrolysis and partial utilization by microorganisms, especially in the endogenous decay phase (Ni et al., 2009).

\subsection{Microbial community of partial nitrification granular sludge}

High-throughput sequencing (HTS) technique was applied for better understanding the microbial community of partial nitrification granular sludge. It was found from Fig. 5A that new bacterial phylotypes continued to emerge even after 9000 reads sampled with pyrosequencing. There were 10001 effective sequences with an average length of 401 base pair obtained at a dissimilarity of 3\% cutoff. Fig. 6B shows the microbial composition structure of the total bacteria at the phylum level in the partial nitrification granular sludge. A total of 9 main phyla were identified from partial nitrification granular sludge. Most bacteria grouped into Proteobacteria and Bacteroidetes were highly enriched in the granular sludge and accounted for $46.86 \%$ and $51.64 \%$ of the total microbes. The other 7 phyla accounted for only a small fraction (less than 1.5\%). The findings of Proteobacteria and Bacteroidetes as dominant phyla in wastewater treatment process have been also well reported in previous studies in MBRs (Ma et al., 2013). It was accepted that Proteobacteria 
appeared to be responsible for $\mathrm{NH}_{4}{ }^{+}-\mathrm{N}$ removal and nitrite accumulation (Wang et al., 2014). Yang et al. (2017) also found that Proteobacteria were most abundant bacterial at phyla level $(92.61 \%, 95.47 \%, 96.61 \%)$ in a partial nitrification zeolite biological aerated filter. Shinya et al. (2010) found that Bacteroidetes abundance of 41\% (for 93 operational taxonomic units) was identified in a granular nitrifying reactor.

At the order level, it was found that the two dominant populations of Sphingobacteriales and Nitrosomonadales accounted for $39.6 \%$ and $24.1 \%$ in the Bacteroidetes and Proteobacteria phyla, respectively (Fig. 5C). The order of Rhodocyclales (14.3\%) is widespread and abundant in wastewater treatment system, which is related to polyphosphate accumulating from a biological $\mathrm{P}$ removal reactor (Zhang et al., 2017). It is well reported that Nitrospira and Nitrosomonas, being NOB and $\mathrm{AOB}$, were the predominant phylogenetic groups at the genus level (Ma et al., 2013). As shown in Fig. 5D, Nitrosomonas affiliated to the AOB were found to be the predominant groups with a proportion of $24.1 \%$. However, Nitrospira-related NOB was not identified, suggesting that NOB was completely washout from the reactor at simultaneous FA and FNA inhibitory effects. Thauera with a proportion of $13.2 \%$ may be the functional bacteria for the partial autotrophic denitrification process (Liu et al., 2017). The detection of Thauera may be attributed to the micro-environment of granules. Due to the DO gradient, the granules can be divided into three zones, i.e. an aerobic zone followed by a micro-oxygen zone and an anoxic (or anaerobic) zone (Gao et al., 2011). Therefore, Thauera had the ability to mediate nitrate or nitrite reduction under either autotrophic or heterotrophic conditions by using hydrogen or 
organic carbon as the electron donor (Wang et al., 2015). Cui et al. (2017) also proved that Thauera became the dominant communities in high nitrite accumulation conditions that were benefited for nitrite accumulation.

\section{Conclusions}

In summary, partial nitrification granular sludge was successfully cultivated in a SBR through shortening settling time as a pretreatment for Anammox. During the stable operation phase, the effluent $\mathrm{NH}_{4}{ }^{+}-\mathrm{N}$ and $\mathrm{NO}_{2}{ }^{-}-\mathrm{N}$ concentrations were average at 277.5 and $280.5 \mathrm{mg} / \mathrm{L}$, whereas $\mathrm{NO}_{3}{ }^{-}-\mathrm{N}$ concentration was only $40.1 \mathrm{mg} / \mathrm{L}$. It is feasible to achieve nitrite accumulation through the combined inhibitory effects of FA and FNA. Only a small fraction of diameter $(<0.5 \mathrm{~mm})$ accounting for less than $0.17 \%$ was found in the matured granules. Nitrosomonas was the predominant AOB in the partial nitrification granular sludge.

\section{Acknowledgements}

This study was supported by the Key Research and Development Plan of Shandong Province (2018GSF117027), Natural Science Foundation of Shandong Province (ZR201702070162), National Natural Science Foundation of China (21777056, 51508226), and QW thanks the Special Foundation for the Taishan Scholar Professorship of Shandong Province and UJN (No.ts20130937).

\section{References}

Adav, S.S., Lee, D.J., Show, K.Y., Tay, J.H. 2008. Aerobic granular sludge: recent advances. Biotechnol. Adv. 26, 411-423. 
Anthonisen, A.C., Loehr, R.C., Prakasam, T.B.S., Srinath, E.G. 1976. Inhibition of nitrification by ammonia and nitrous acid. J. Water Pollut. Control. Fed. 48, 835-852.

APHA, AWWA, WEF. 2005. Standards methods for the examination of water and wastewater. 21st ed, Washington, D.C.

Bao, R., Yu, S., Shi, W., Zhang, X., Wang, Y. 2009. Aerobic granules formation and nutrients removal characteristics in sequencing batch airlift reactor (SBAR) at low temperature. J. Hazard. Mater. 168, 1334-1340.

Blackburne, R., Yuan, Z., Keller, J. 2008. Partial nitrification to nitrite using low dissolved oxygen concentration as the main selection factor. Biodegradation. 19, 303-312.

Chen, W., Westerhoff, P., Leenheer, J.A., Booksh, K. 2003. Fluorescence excitation-emission matrix regional integration to quantify spectra for dissolved organic matter. Environ. Sci. Technol. 37, 5701-5710.

Cui, B., Liu, X., Yang, Q., Li, J., Zhou, X., Peng, Y. 2017. Achieving partial denitrification through control of biofilm structure during biofilm growth in denitrifying biofilter. Bioresour. Technol. 238, 223-231.

D’Abzac, P., Bordas, F., Van Hullebusch, E., Lens, P.N., Guibaud, G. 2010. Extraction of extracellular polymeric substances (EPS) from anaerobic granular sludges: comparison of chemical and physical extraction protocols. Appl. Microbiol. Biotechnol. 85, 1589-1599.

Gao, D., Liu, L., Liang, H., Wu, W.M. 2011. Aerobic granular sludge: characterization, mechanism of granulation and application to wastewater treatment. Crit Rev Biotechnol, 31, 137-152.

Guo, J., Peng, Y., Huang, H., Wang, S. Ge, S., Zhang, J., Wang, Z. 2010. Short-and long-term effects of temperature on partial nitrification in a sequencing batch reactor treating domestic wastewater. J Hazard Mater. 179, 471-479.

Iaconi, C.D., Ramadori, R., Lopez, A., Passino, R. 2006. Influence of hydrodynamic shear forces on properties of granular biomass in a sequencing batch biofilter reactor. Biochem Eng J. 30, 152-157.

Joss, A., Salzgeber, D., Eugster, J., König, R., Rottermann, K., Burger, S., Fabijan, P., Leumann, S., Mohn, J., Siegrist, H. 2009. Full-scale nitrogen removal from digester 
liquid with partial nitritation and anammox in one SBR. Environ. Sci. Technol. 43, $5301-5306$.

Lackner, S., Gilbert, E.M., Vlaeminck, S.E., Joss, A., Horn, H., van Loosdrecht, M.C. 2014. Full-scale partial nitritation/anammox experiences-an application survey. Water Res. $55,292-303$.

Laspidou, C.S., Rittmann, B.E. 2002. A unified theory for extracellular polymeric substances, soluble microbial products, and active and inert biomass. Water Res. 36, 2711-2720.

Liang, Y., Li, D., Zeng, H., Zhang, C., Zhang, Jie.2015. Rapid start-up and microbial characteristics of partial nitrification granular sludge treating domestic sewage at room temperature. Bioresour. Technol. 196, 741-745.

Li, J., Wei, J., Ngo, H.H., Guo, W., Liu, H., Du, B., Wei, Q., Wei, D. 2018. Characterization of soluble microbial products in a partial nitrification sequencing batch biofilm reactor treating high ammonia nitrogen wastewater. Bioresour. Technol. 249, 241-246.

Li, X.Y., Yang, S. 2007. Influence of loosely bound extracellular polymeric substances (EPS) on the flocculation, sedimentation and dewaterability of activated sludge. Water Res. $41,1022-1030$

Liu, X.W., Yu, H.Q., Ni, B.J. Sheng, G.P. 2009. Characterization, modeling and application of aerobic granular sludge for wastewater treatment. Biotechnology in China I. Springer Berlin Heidelberg. 275-303.

Liu, Y., Fang, H.H.P. 2003. Influence of extracellular polymeric substances (EPS) on flocculation, settling, and dewatering of activated sludge. Crit Rev Environ Sci Technol. 33, 237-273.

Liu, Y., Yang S.F., Tay, J.H. 2004. Improved stability of aerobic granules by selecting slow-growing nitrifying bacteria. J Biotechnol. 108, 161-169.

Liu, C., Li, W., Li, X., Zhao, D., Ma, B., Wang, Y., Liu, F., Lee, D.J. 2017. Nitrite accumulation in continuous-flow partial autotrophic denitrification reactor using sulfide as electron donor. Water Res. 243, 1237-1240

Liu, Y.Q., Liu, Y., Tay, J.H. 2004. The effects of extracellular polymeric substances on the formation and stability of biogranules. Appl. Microbiol. Biotechnol. 65, 143-148.

Luo, J., Hao, T., Wei, L., Mackey, H.R. Lin, Z., Chen, G.H. 2014. Impact of influent COD/N 
ratio on disintegration of aerobic granular sludge. Water Res. 62, 127-135.

Ma, B., Wang, S., Cao, S., Miao, Y., Jia, F., Du, R., Peng, Y. 2016. Biological nitrogen removal from sewage via anammox: recent advances. Bioresour. Technol. 200, 981-990.

Ma, J., Wang, Z., Yang, Y., Mei, X., Wu, Z. 2013. Correlating microbial community structure and composition with aeration intensity in submerged membrane bioreactors by 454 high-throughput pyrosequencing. Water Res. 47, 859-869.

Miao, Y., Zhang, L., Li, B., Zhang, Q., Wang, S., Peng, Y. 2017. Enhancing ammonium oxidizing bacteria activity was key to single-stage partial nitrification-anammox system treating low-strength sewage under intermittent aeration condition. Bioresour. Technol. 231, 36-44.

Ni, B.J., Fang, F., Xie, W.M., Sun, M., Sheng, G.P., Li, W.H., Yu, H.Q. 2009. Characterization of extracellular polymeric substances produced by mixed microorganisms in activated sludge with gel-permeating chromatography, excitation-emission matrix fluorescence spectroscopy measurement and kinetic modeling. Water Res. 43, 1350-1358.

Ni, B.J., Xie, W.M., Liu, S.G., Yu, H.Q., Wang, Y.Z., Wang, G., Dai, X.L. 2009. Granulation of activated sludge in a pilot-scale sequencing batch reactor for the treatment of low-strength municipal wastewater. Water Res. 43, 751-761.

Okabe, S., Oshiki, M., Takahashi, Y., Satoh, H. 2011. Development of long-term stable partial nitrification and subsequent anammox process. Bioresour. Technol. 102, 6801-6807.

Park, S., Chung, J., Rittmann, B.E., Bae, W. 2015. Nitrite accumulation from simultaneous free-ammonia and free-nitrous-acid inhibition and oxygen limitation in a continuous-flow biofilm reactor. Biotechnol Bioeng. 112, 43-52.

Pollice, A., Tandoi, V., Lestingi, C. 2002. Influence of aeration and sludge retention time on ammonium oxidation to nitrite and nitrate. Water Res. 36, 2541-2546.

Rathnayake, R., Song, Y., Tumendelger, A., Oshiki, M., Ishii, S., Satoh, H., Toyoda, S., Yoshida, N., Okabe, S. 2013, Source identification of nitrous oxide on autotrophic partial nitrification in a granular sludge reactor. Water Res. 47, 7078-7086.

Sheng, G.P., Yu, H.Q. 2006. Characterization of extracellular polymeric substances of aerobic and anaerobic sludge using three-dimensional excitation and emission matrix 
fluorescence spectroscopy. Water Res. 40, 1233-1239.

Sheng, G.P., Yu, H.Q., Li, X.Y. 2010. Extracellular polymeric substances (EPS) of microbial aggregates in biological wastewater treatment systems: A review. Biotechnol Adv. 28, 882-894.

Shinya, M., Mayu, K., Goro, S., Akihiko, T., Yoshiteru, A., Satoshi, T., Cristian, P., Loosdrecht, M.C.M., Van. 2010. Microbial community structure in autotrophic nitrifying granules characterized by experimental and simulation analyses. Environ Microbiol. 12, 192-206.

Su K Z, Yu H Q. 2005. Formation and characterization of aerobic granules in a sequencing batch reactor treating soybean-processing wastewater. Environ. Sci. Technol. 39, $2818-2827$.

Shammi, M., Pan, X., Mostofa, K.M.G., Zhang, D., Liu, C.Q. 2017. Photo-flocculation of microbial mat extracellular polymeric substances and their transformation into transparent exopolymer particles: Chemical and spectroscopic evidences. Sci Rep. 7, 9074.

Vadivelu, V.M., Yuan, Z., Fux, C., Keller, J. 2006. The inhibitory effects of free nitrous acid on the energy generation and growth processes of an enriched Nitrobacter culture. Environ. Sci. Technol. 40, 4442-4448.

Vázquez-Padín, J.R., Figueroa, M., Campos., L. Mosquera-Corral., A. Méndez., R. 2010. Nitrifying granular systems: a suitable technology to obtain stable partial nitrification at room temperature. Sep Purif Technol. 74, 178-186.

Wan, C., Sun, S., Lee, D.J., Xiang, L., Li, W., Xue, Y., Pan, X. 2013. Partial nitrification using aerobic granules in continuous-flow reactor: Rapid startup. Bioresour. Technol. 142C, $517-522$.

Wang, B.B., Liu, X.T., Chen, J.M., Peng, D.C., He, F. 2017. Composition and functional group characterization of extracellular polymeric substances (EPS) in activated sludge: the impacts of polymerization degree of proteinaceous substrates. Water Res.129, 133-142.

Wang, L.K., Zeng, G.M., Yang, Z.H., Luo, L.L., Xu, H.Y., Huang, J. 2014. Operation of partial nitrification to nitrite of landfill leachate and its performance with respect to 
different oxygen conditions. Biochem Eng J. 87, 62-68.

Wang, R., Zheng, P., Zhang, M., Zhao, H.P., Ji, J.Y., Zhou, X.X., Li, W. 2015.

Bioaugmentation of nitrate-dependent anaerobic ferrous oxidation by heterotrophic denitrifying sludge addition: A promising way for promotion of chemoautotrophic denitrification. Bioresour. Technol. 197, 410-415.

Wei, D., Xue, X., Yan, L., Sun, M., Zhang, G., Shi, L., Du, B. 2014. Effect of influent ammonium concentration on the shift of full nitritation to partial nitrification in a sequencing batch reactor at ambient temperature. Chem Eng J. 235, 19-26.

Wei D, Qiao Z, Zhang, Y., Hao, L., Si, W., Du, B.,Wei, Q. 2013. Effect of COD/N ratio on cultivation of aerobic granular sludge in a pilot-scale sequencing batch reactor. Appl. Microbiol. Biotechnol. 97, 1745-1753.

Weber, S.D., Ludwig, W., Schleifer, K.H., Fried, J. 2007. Microbial Composition and Structure of Aerobic Granular Sewage Biofilms. Appl Environ Microbiol. 73, 6233-6240.

Yang, Y., Chen, Z., Wang, X., Zheng, L. Gu, X.2017. Partial nitrification performance and mechanism of zeolite biological aerated filter for ammonium wastewater treatment. Bioresour. Technol. 241, 473-481.

Zhang L, Yang J, Furukawa K. 2010. Stable and high-rate nitrogen removal from reject water by partial nitrification and subsequent anammox. J Biosci Bioeng. 110, 441-448.

Zhang, Y., Islam, M.S., Mcphedran, K.N., et al. 2017. A comparative study of microbial dynamics and phosphorus removal for a two side-stream wastewater treatment processes. Rsc Adv. 7, 45938-45948. 


\section{Figure captions}

Fig. 1 Evolution of nitrogen compounds in the influent and effluent during the achievement and maintenance of partial nitrification granular sludge reactor.

Fig. 2 Settling property and size distribution of partial nitrification reactor: (A) MLSS and SVI values; (B) Size distributions.

Fig. 3 Variation of EPS contents during the achievement and maintenance of partial nitrification granular sludge process.

Fig.4 3D-EEM spectra of EPS samples from partial nitrification sludge granulation process: (A) day 1; (B) day 70; (C) day 163; (D) day 245.

Fig. 5 Rarefaction curves of the sequencing results (A) and microbial composition structure of the total bacteria in partial nitrification granular sludge at the phylum level (B); order level (C) and genus level (D). 


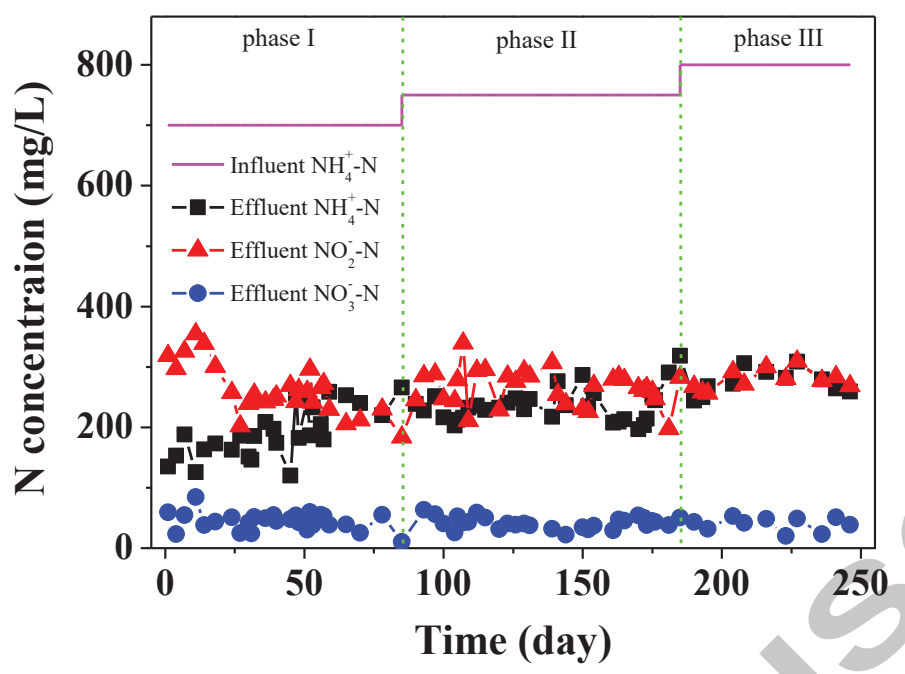

Fig.1 Evolution of nitrogen compounds in the influent and effluent during the achievement and maintenance of partial nitrification granular sludge reactor. 
A

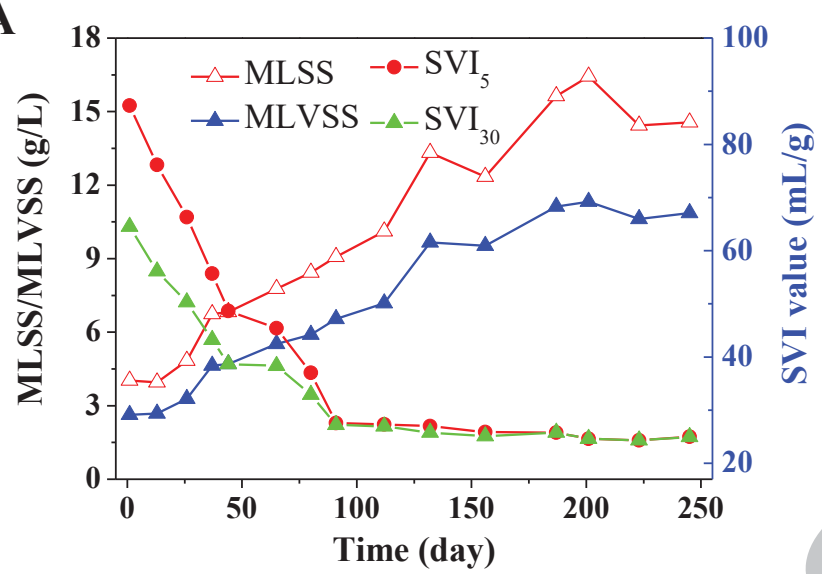

B

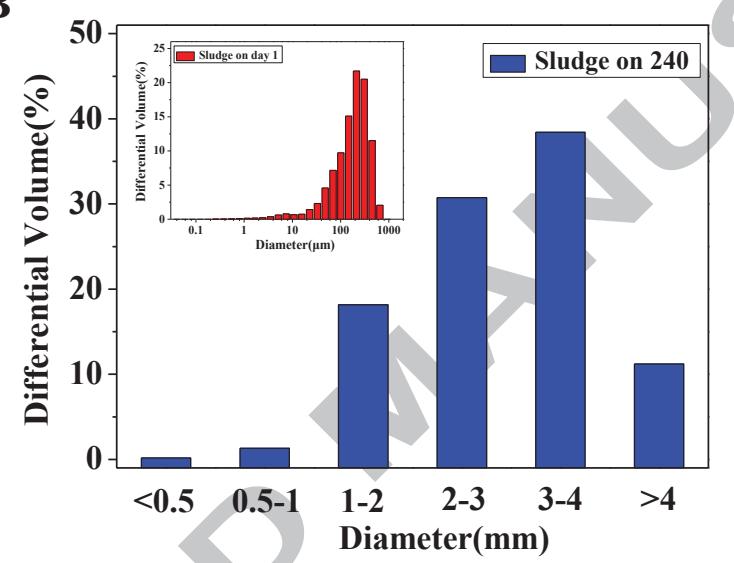

Fig. 2 Settling property and size distribution of partial nitrification reactor: (A) MLSS and SVI values; (B) Size distributions. 


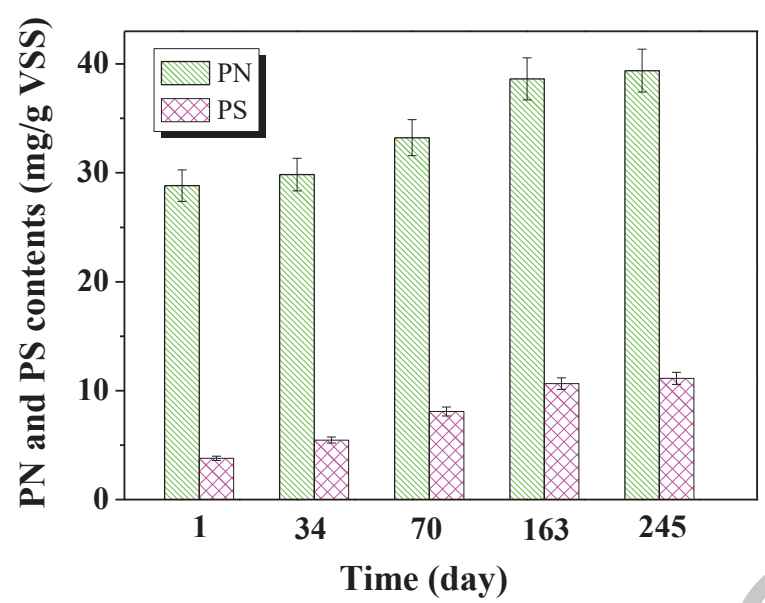

Fig. 3 Variation of EPS contents during the achievement and maintenance of partial nitrification granular sludge process. 

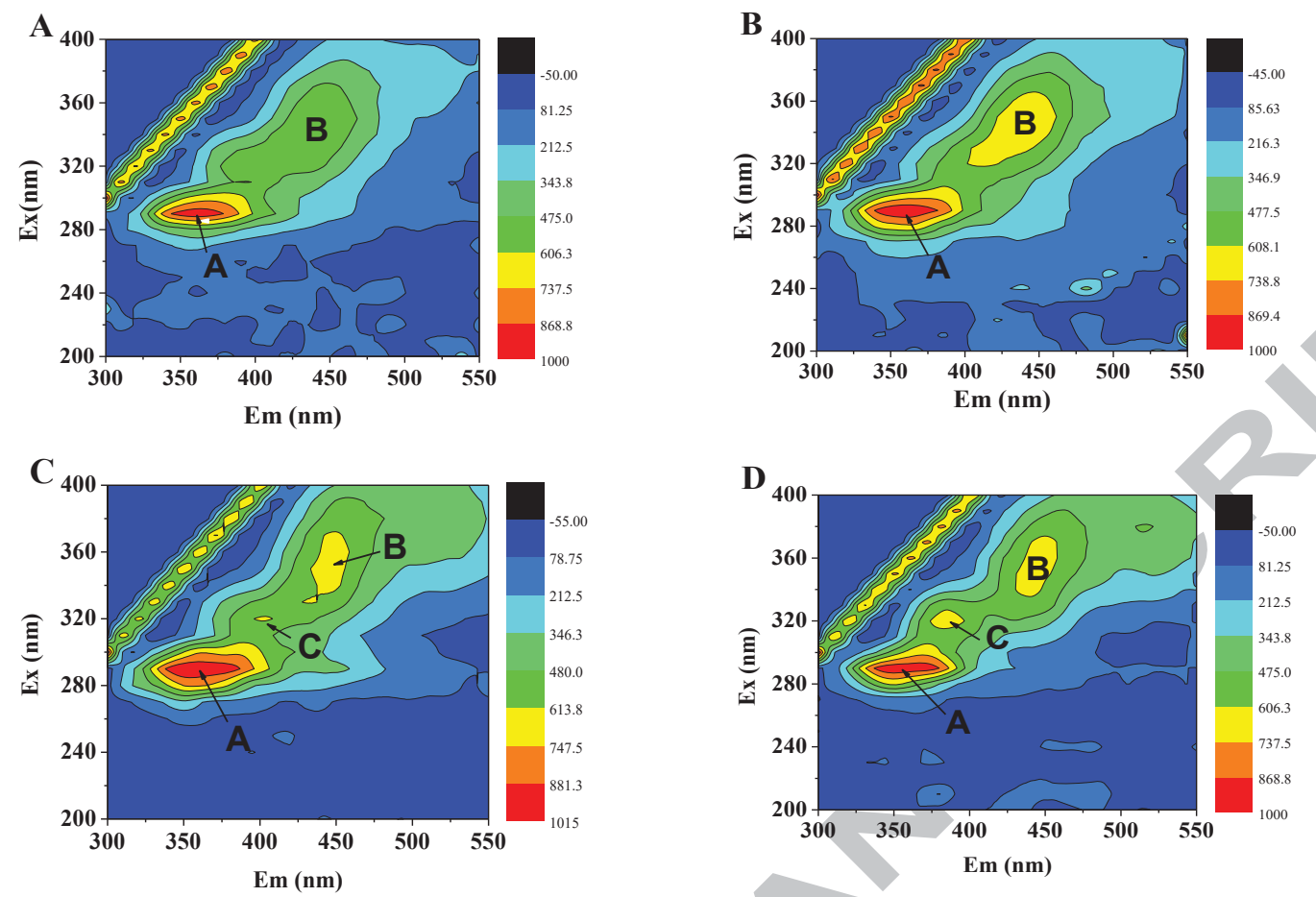

Fig.4 3D-EEM spectra of EPS samples from partial nitrification sludge granulation process: (A) day 1; (B) day 70; (C) day 163; (D) day 245. 
A

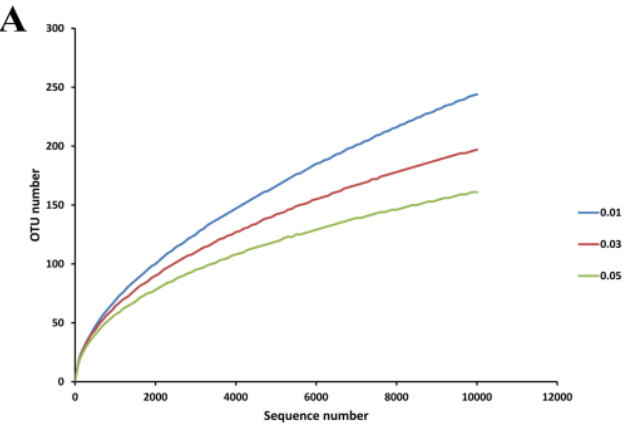

C

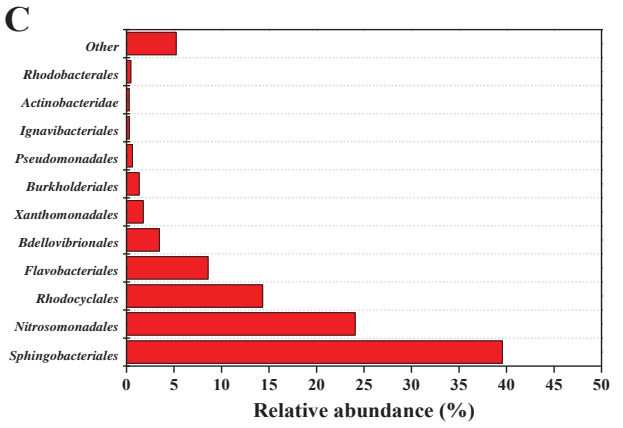

B

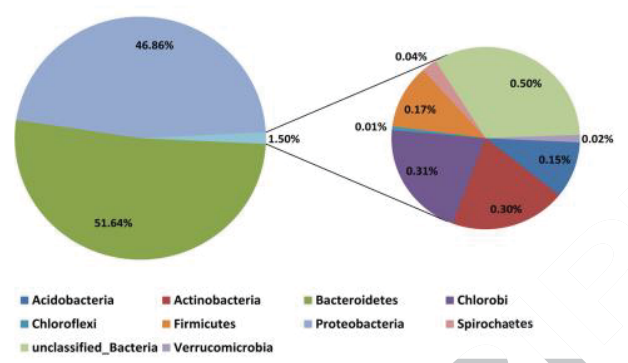

D

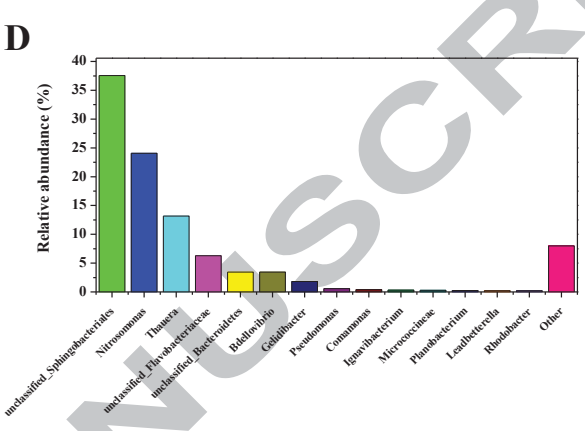

Fig. 5 Rarefaction curves of the sequencing results (A) and microbial composition structure of the total bacteria in partial nitrification granular sludge at the phylum level (B); order level (C) and genus level (D). 
Table 1 Detailed fluorescence spectral parameters of EPS samples during partial nitrification granulation process.

\begin{tabular}{ccccccc}
\hline \multirow{2}{*}{$\begin{array}{c}c \\
\text { PPS }\end{array}$} & \multicolumn{2}{c}{ Peak A } & \multicolumn{2}{c}{ Peak C } \\
Simples & Ex/Em & Intensity & Ex/Em & Intensity & Ex/Em & Intensity \\
\hline A & $290 / 361.5$ & 960.4 & $350 / 440$ & 591.2 & $/$ & \\
B & $290 / 358$ & 993.2 & $340 / 440$ & 726.5 & $/$ & \\
C & $290 / 353$ & 1010.7 & $360 / 449$ & 662.7 & $320 / 402$ & 629.4 \\
D & $290 / 350$ & 974.0 & $360 / 446$ & 654.9 & $320 / 384$ & 672.5 \\
\hline
\end{tabular}

